HENRY IV 


\section{HENRY IV}

Chris Given-Wilson

YALE UNIVERSITY PRESS

NEW HAVEN AND LONDON 


\section{Copyright (C) 2016 Chris Given-Wilson}

All rights reserved. This book may not be reproduced in whole or in part, in any form (beyond that copying permitted by Sections I07 and I08 of the U.S. Copyright Law and except by reviewers for the public press) without written permission from the publishers.

For information about this and other Yale University Press publications, please contact: U.S. Office: sales.press@yale.edu_www.yalebooks.com

Europe Office: sales@yaleup.co.uk_www.yalebooks.co.uk

Set in Baskerville by IDSUK (DataConnection) Ltd

Printed in Great Britain by TJ International Ltd, Padstow, Cornwall

Library of Congress Cataloging-in-Publication Data

Given-Wilson, Chris.

Henry IV / Chris Given-Wilson.

pages $\mathrm{cm}$

ISBN 978-O-300-I54I9-I (cl : alk. paper)

I. Henry IV, King of England, I367-I4I3. 2. Great Britain-Kings and rulers-

Biography. 3. Great Britain-History-Henry IV, I399-I4I3. I. Title.

DA255.G58 2016

[B]

942.04' $1092-\mathrm{dc} 23$

$$
2015023658
$$

A catalogue record for this book is available from the British Library.

IO 987765432 I 
For Alice and all our family 
